\title{
A CROSS-DISCIPLINARY TOOLKIT TO ASSESS THE RISK OF FAECAL INDICATOR LOSS FROM GRASSLAND FARM SYSTEMS TO SURFACE WATERS
}

David M. Oliver* ${ }^{1}$, Rob D. Fish ${ }^{2}$, Chris J. Hodgson ${ }^{3}$, A. Louise Heathwaite ${ }^{1}$, Dave R. Chadwick ${ }^{3}$ and Michael Winter ${ }^{2}$

1 Centre for Sustainable Water Management, Lancaster Environment Centre, Lancaster University, Lancaster, LA1 4AP, UK.

2 Centre for Rural Policy Research, Department of Politics, University of Exeter, Amory Building, Exeter EX4 6RJ

3 North Wyke Research, Okehampton, Devon EX20 2SB

\author{
Abbreviations \\ FIO: Faecal indicator organism \\ FYM: Farmyard manure \\ LU: Livestock units \\ rBWD: revised Bathing Waters Directive \\ WFD: Water Framework Directive
}

*Corresponding author: David M. Oliver (․m.oliver@lancaster.ac.uk). Tel: +44 (0)1524 510231, Fax: +44 (0)1524 510217. 


\section{Abstract}

Diffuse microbial pollution from agriculture is a key contributor to water quality impairment. Reducing the risk of microbial contamination of watercourses from agricultural sources requires both environmentally appropriate and socially acceptable mitigation and management approaches. A cross-disciplinary toolkit for on-farm microbial risk assessment is presented that can represent both social and environmental factors promoting or preventing the accumulation of faecal indicator organisms (FIOs) within the farm environment, and also their subsequent transfer to watercourses. Four key risk criteria were identified as governing FIO loss from land to water. These were 'accumulating E. coli burden to land', 'landscape transfer potential', 'infrastructure' and 'social and economical obstacles to taking action'. The toolkit can be used to determine (i) the relative risk of a farm enterprise contributing to microbial watercourse pollution and (ii) appropriate and targeted mitigation to reduce the risk of FIO loss from land to water. A comparison of the toolkit output with microbiological water quality draining from three contrasting grassland farm enterprises provided a preliminary evaluation of the prototype approach. When applied to 31 grassland farm enterprises the toolkit suggested that $0 \%$ were categorised as negligible risk, $32 \%$ low, $65 \%$ medium, $3 \%$ high and $0 \%$ very high risk. Such qualitative risk-based tools can assist the policy community not only to target high risk areas, but also to develop mitigation strategies that are sensitive to the different ways in which risk is produced. Capacity for long-term cross-disciplinary research is argued to be the means by which these integrated and more sustainable solutions may emerge.

Keywords: cross-disciplinary, decision support, E. coli, faecal indicators, farm, mitigation, risk 


\section{Introduction}

Diffuse microbial pollution from agriculture is recognised as a major contributor to water quality impairment (Kay et al., 2007; Kay et al., 2008a; Monaghan et al., 2008). Faecallyderived pathogens such as Escherichia coli O157:H7 can impact not only on water quality but also human health. Non-pathogenic microbial parameters, such as faecal indicator organisms (FIOs), can be used as surrogate measures of infection risk to humans (Kay et al., 2007) and are more easily monitored and studied in both laboratory and field environments. Risk assessment approaches addressing microbial transfers from farm environments have tended to focus on the 'farm-to-fork' pathway of exposure (e.g. Havelaar et al., 2007; Duffy et al., 2008), with approaches for assessing the risk of microbial impairment of watercourses at the farm level remaining largely undeveloped. Yet the current trend suggests that human illness through environmental exposure to pathogens is increasing because the control of microbial transmission in farm enterprises is more difficult relative to food manufacturing systems (Strachan et al., 2006). Furthermore, the policy and scientific context is changing. Emerging regulatory frameworks, such as the Water Framework Directive (WFD) (CEC, 2000) in Europe, and the revised Bathing Waters Directive (rBWD) (CEC, 2006) are driven, in part, by recognition that microbial watercourse pollution is an important vector of disease transmission, and that the 'farm-to-field-to-water' pathway may be significant in contributing FIOs and potential pathogens to receiving waters. Thus, land and farm management approaches designed to minimise microbial loss from land to water can be promoted to reduce the agricultural contribution of FIOs to designated bathing waters.

While Vinten et al. (2008) suggest that there is a scarcity of quantitative information available to identify where FIO mitigation efforts would be most economically and technically effective we argue that qualitative risk assessment can often prove just as useful as quantitative strategies (Heathwaite et al, 2003). In fact, Goss and Richards (2008) argue that development of a risk-based index of the potential for pathogens from agricultural activity to 
impact on water quality is required as an interim stage in the establishment of a fully quantitative microbial risk assessment approach.

This paper outlines an approach to farm scale microbial risk assessment through which it may be possible to apportion and act upon such risks in effective and measured ways. There is a growing body of empirical FIO-related science which can form the 'evidence-base' for good regulatory practice (Kay et al., 2008a) and the conceptual toolkit presented in this paper has been designed around the findings of existing research. The cross-disciplinary toolkit detailed in this paper is an integrated attempt to develop a more holistic account of FIO risk and its management, as promoted by Chadwick et al. (2008) in their case for an interdisciplinary approach. Understanding the factors that promote or prevent the transfer of FIOs and potential pathogens from livestock farming systems to watercourses is complex, and demands models of working that are explicitly cross-disciplinary in design. Not only must assessments of risk account for heterogeneous physical landscapes and farm infrastructures, they must consider the wider cultural and political economy of farming, particularly the processes that shape prevailing attitudes and influence farmers' decisions to take action in complex ways (Burton and Wilson 2006). Approaches to agricultural risk assessment that fail to embrace both social and natural aspects of the farm environment may lead to pathways of environmental protection that are disproportionate or inappropriate in conception (Nowak et al., 2006).

The aim of this study was to (i) combine the knowledge of social and natural scientists and use established natural and socio-economic indicators of risk to develop an integrated conceptual framework for a farm scale FIO risk assessment toolkit that allows those involved in land management to prioritise on-farm mitigation efforts for maximum effect; and (ii) provide a preliminary on-farm evaluation of the toolkit by assessing the microbiological water quality of streams draining three contrasting grassland farms in the Taw catchment, North Devon (a predominantly surface water catchment). 


\section{Materials and methods}

\subsection{The toolkit}

Generic E. coli was used in the design of our toolkit because it is a relatively well researched FIO allowing us to draw on a body of published research in the development of our work. The toolkit is a farm scale tool, consisting of four key risk criteria judged to influence FIO loss to water, namely:

- $\quad$ accumulating E. coli burden to land;

- landscape transfer potential;

- infrastructural characteristics of the farm enterprise;

- social and economic obstacles to taking action.

Insert Table 1

The factors defining each of the risk criteria are listed in Table 1, along with the sources of data required to populate each risk factor. The toolkit was designed to be parsimonious and to include only key risk factors whose contribution could be justified (by the existing empirical evidence-base) in terms of their impact on surface water receptors and whose site specific data could be easily obtained by a field assessor and farm survey. The first criterion - E. coli burden to land - is designed to incorporate into the toolkit the FIO risks that arise from the application and deposition of manures and faeces during farming activities. It represents all $E$. coli inputs to land and is then normalised by the area of the farm with equal application/deposition to land assumed throughout the farm boundary. The second and third criteria - Landscape transfer potential and Characteristics of infrastructure - encompass risks arising from the physical characteristics and arrangement of the farmed landscape. 'Transfer potential' relates to the role of natural features (such as slope and soil type) on fostering or preventing FIO movement whereas 'infrastructure' relates to the role of technical and 
historical features, (such as the extent of farmyard drainage systems; or fenced-off watercourses). Infrastructure also accounts for point source inputs of FIOs to agricultural environments associated with animal manure storage and hard standings and buildings used by livestock (Kay et al., 2008b). It is important to stress that rainfall was not built specifically into the 'transfer potential' risk criterion. Instead, 'transfer potential' is more concerned with the physical features of the landscape that may promote or hinder runoff generation should rainfall occur. However, rainfall is important in driving transfer processes. In this preliminary study, all farms assessed were linked spatially to a geographical location within the Taw catchment, North Devon, but for application of the toolkit in other geographical regions of the UK it would be necessary to refer to a rainfall 'look-up-table', most notably in the form of the nationally available UK 30 year average rainfall records (Morris, 1999). This would allow for identification of the annual rainfall ( $\mathrm{mm}$ ) associated with each farm location so to relate toolkit output with associated relative rainfall levels across distinct areas of the UK. The fourth criterion, social and economic obstacles to taking action addresses the structural and attitudinal factors that limit a farmer's ability and inclination to manage for FIO risk. Here, risk is understood to be the function of economic capacity (such as the influence of debt), values and competency (such as knowledge of diffuse pollution) and responsibility (such as the underlying impact of regulation).

In our toolkit these four components form the basis for an analytical framework by which an assessment of overall farm riskiness (with respect to both likelihood and magnitude of FIO loss from land to water) is conveyed. Microbial risk assessment involves determining the product of likelihood of microbial contamination and the magnitude of associated consequences, the latter being the impact of the contaminated receiving waters draining from the catchment to a designated bathing water sampling location (assumed equal for all farms in this study). The framework is designed as a means of identifying factors on-farm which should be targeted for mitigation and intervention. The tool conveys this information visually 
on the basis of four axes, each representing one of the components of risk (see Figure 1). Each of the axes are made operational through recourse to quite different data sets, which have been normalised to a sliding scale of 0 (minimal risk) through 10 (worst-case risk) as a way of comparing the relative influence of risk criteria in given circumstances. A concurrent plotting of each relative risk score allows us to produce a diagrammatic representation of: i) the farm's 'overall' riskiness, coupled with ii) an assessment of the direction of influence of key risk criteria. The former is represented by the magnitude of co-ordinates plotted on each axis, the latter by its shape. An example of a hypothetical farm scored using this toolkit is depicted in Figure 1. In this example the farm generates a large E. coli burden to land and the farmer faces significant obstacles to taking action. While infrastructure is well maintained, the landscape characteristics promote run off. Importantly, the framework assigns equal importance to these risk criteria in order to make an assessment. This is because the approach avoids allocating elevated importance to a particular criterion over another in making an overall judgment of risk. There is currently no integrated scientific and social scientific evidence base that has allowed us to make such a distinction and this reflects the prototypical nature of this work.

\section{Insert Fig 1}

\subsection{Operationalising the tool kit}

To make the toolkit operational a series of judgements were made regarding how each axis functions. In the case of accumulating E. coli burden to land, the axis accounts for a first approximation of E. coli applied and deposited (via manures or faeces) to land per hectare over an annual period. Farm livestock numbers and manure spreading activity (obtained via farmer survey) provide key information to generate an E. coli burden through time. Importantly, all manure spreading was conducted by the farmers rather than by contractors so survey details were considered as accurate as possible. Parameters and coefficients used to 
generate indicative accumulating E. coli burden to land for farms are detailed in Table 2. E. coli burden can be calculated based on biological rules (exponential die-off) and empirical data relating to manure generation per animal type. The dynamic load is derived using calculations that relate daily additions of fresh faeces from all livestock and applied manures to a simultaneous exponential die-off equation (Equation 1) as governed by season and animal/manure type:

$$
y=A e^{-b x}
$$

Where $\mathrm{y}$ is the concentration on day $\mathrm{x}, \mathrm{A}$ is the initial concentration, and $\mathrm{b}$ is the appropriate exponential die-off constant. Each additional day accounts for the contribution of fresh faecal additions (zero die-off) plus the store of E. coli from all previous days (with accumulating die-off accounted for). To constrain farmer uncertainties related to slurry and FYM volumes produced per farm we back-calculated estimates of manure generated per day based on farm livestock numbers and used experimentally derived manure store die-off rates to estimate the E. coli contributed to land for each application. A critical assumption was that any FYM undergoing storage (with no fresh additions) for a period exceeding three months would contain negligible FIO levels as supported by literature evidence (Nicholson et al., 2005). Accumulating E. coli burden to land is dynamic through time and space but by using the toolkit on an annual time-step and at the farm scale we were able to limit the uncertainties attributed to spatial distributions of livestock movements and their excretions across fields and instead consider the whole farm input for a given enterprise for a given year. To normalise for farm area the total farm E. coli burden to land was divided by farm area using available GIS data. To rank each farm in a relative manner based on E. coli burden to land we defined a 'worst case scenario' for E. coli burden; one whereby a 1ha area is grazed by three beef cattle and calves, 20 sheep and 20 lambs. This gave a stocking density of eight LU ha ${ }^{-1}$ and represented a realistic upper level of stocking densities in the UK. A high number of sheep and lambs were chosen because they shed higher numbers of $E$. coli relative to other 
livestock (and also because sheep numbers are high in the Taw catchment). An example of the modelled E. coli burden for a dairy farm surveyed in our study is shown in Figure 2 to demonstrate the time-series input of E. coli from both grazing period and slurry applications (and hence combined input). In the example shown in Figure 2, dairy cattle graze between April and September and the farmer spreads slurry on a weekly basis, throughout the year, using a rotational spreading programme. Such high frequency spreading is typical of farms with little storage capacity - 16\% of dairy farms in England and Wales have less than 1 month storage (Smith et al., 2001). However, the farm scale nature of the toolkit does not allow for differentiating which fields have had manure applied. The toolkit extracts the value of maximum E. coli burden from each farm time-series plot and uses this as a relative indicator of maximum potential burden per farm, irrespective of rainfall. The maximum E. coli burden always coincides with the time window of the designated bathing water season (May through September) because of faecal inputs from grazing cattle and sheep and so represents a legitimate 'at-risk' period too.

Insert Table 2 and Fig 2

In the case of 'Infrastructure', 'Transfer potential' and 'Obstacles', all contain a series of discrete components which build an overall impression of axis significance. The toolkit required data in the form of readily accessible field data, farmer knowledge and nationally available GIS databases (digital terrain models and digitised ordnance survey maps: see Table 1). While the rationale for inclusion of the risk factors within each of the risk criteria was based on current empirical research in the area of FIO-related watercourse pollution, determining their relative importance when operating at the farm scale has been beyond the scope of many research studies. In order for us to make some working assessments of how factors embedded in these risk criteria could be assigned significance, we initiated a process of expert consultation: one that involved individuals with different disciplinary expertise to pass judgement on the relative importance of possible controls on FIOs by way of a numerical 
weighting schedule. In particular, this process involved natural science experts gauging the relative importance of bio-physical and management variables, and social-science experts passing judgement on social processes and structures. This process was not about generating an extensive sample of views. Rather, it was about developing indicative responses from relevant disciplines that could help make our risk tool operational. A more detailed analysis and discussion of these expert consultation exercises is described in Fish et al. (submitted). Briefly, this approach made use of an electronic expert consortium comprising 28 members. Members were selected based on their research history and expertise in their field. All 16 natural science experts were required to have had experience within the sphere of FIO research in order to qualify for inclusion within the electronic consortium (c.f. Cornelissen et al., 2003). Inclusion of experts from various disciplines ensured that specific understandings inherent to particular disciplines were given an opportunity to contribute to the risk index and compensated for conflicting points of view. The weightings reflect the current perceptual understanding of microbiologists, soil and contaminant scientists, manure management experts, policy makers and geographers. For social science we solicited the views of those working in rural geography, agricultural studies, agricultural economics, rural sociology and political science. The social scientists included in the process were identified via their interests in rural environmental change, of which watercourse pollution was a substantive concern. The foundations of the framework are the experts' judgement, based on knowledge and experience gained during their professional activities. To avoid influencing opinion, the experts were contacted electronically (via email) without forewarning and requested to assign an expert weighting to each risk factor listed in a formatted spreadsheet within a 4 week period. Importantly, the ranges of expert weightings have been retained and may be used in the future for uncertainty assessment (Refsgaard et al., 2007).

Risk factor weightings are shown in Table 3 together with an overview of how they were characterised and scored in relation to 'real world' data sets. These data sets included i) a detailed farm management survey (135 structured questions - available upon request from 
author) of 31 farmers and ii) nationally available GIS datasets (derived from NextMap Britain 5m DTM) and ordnance survey digital maps. Details of each farm were recorded and then each risk factor within each of the four risk criteria was assigned a magnitude in accordance with the scoring system shown in Table 3 (whereby a score of 0 equated to lowest risk and score of 1.0 equated to highest risk associated with each risk factor, given the farm circumstances). This score was then multiplied by the expert weighting (relative importance) associated with each risk factor. The conversion of farm survey responses into a scoring system for magnitude of risk is complex. Currently our study has presented this scoring system (Table 3) as a first approximation and is flexible so that it can be updated with additional information. Specific information for FIOs is limited and often we have assumed linear responses between a risk factor and its associated magnitude of risk (e.g. increase in slope is directly proportional to increase in risk). Linear responses are assumed in this first approximation because scale dependent data or evidence relating to critical 'tipping' points attributed to environmental variables are sparse for many of the risk factors.

Insert Table 3

Each axis within the risk assessment toolkit was normalised so that a worst case scenario would be represented as a risk index score of 10 . Thus a risk index score of 10 on an axis represented a scenario indicative of both i) high likelihood of FIO loss from land to water occurring and ii) high magnitude of FIO loss from land to water occurring. The total risk score (or co-ordinate per axis) for each risk criterion was defined by Equation 2:

Risk score per axis $=10 \Sigma$ (magnitude $\mathrm{x}$ weighting / worst-case magnitude $\mathrm{x}$ weighting)

A farm scoring 10 on all axes (sum of 40 ) would equate to a polygon risk score of $100 \%$ and would be at most risk of contributing to microbial watercourse impairment. All other scores were normalised to this scale. The relative risk values (polygon scores) generated by the 
toolkit were subdivided into 5 risk categories $(0-20=$ negligible; $21-40=10 w ; 41-60=$ medium; $61-80=$ high; and $>80=$ very high).

\subsection{Farm description}

In total, 31 livestock farms were assessed using the toolkit. All were predominantly grassland with on average $<18 \%$ of land area used for arable/forage crops. However, only a selection of these farms could be monitored for microbiological water quality. A brief 'storyboard' linked to three farms follows, based on information collected via farm survey, visual assessment, and GIS databases. Importantly, if available, farm management plans were requested as part of the farm survey to help inform on-farm characteristics (e.g. Defra manure management plan; Defra soil management plan) (Defra, 2003; Defra, 2005).

\subsubsection{Farm A}

Farm $\mathrm{A}$ is a 81 ha suckler beef enterprise. The farmer has sufficient labour to manage his enterprise effectively and although the farm carries debt this does not impact on his management decisions. He has never received any grant aid for improving waste management. The farmer holds an 'entry level stewardship' agreement, is part of the Assured Combinable Crops (ACC) Beef \& Lamb quality assurance scheme and has attended farmer discussion groups on manure management. He is aware of his responsibilities under cross compliance but is not able to explain what diffuse pollution means. He is university educated and has undertaken courses in land and livestock management at the local agricultural college. The farm is situated on slightly undulating land. A small stream re-emerges close to main activity of the farm, having undergone subsurface flow following the route of a drainage ditch. There are some significant areas of heavy clay soil but no soil compaction. There exists a network of plastic pipes and drainage tiles which function well. Stock has access to streams for drinking, but not for crossing. The area of the hard standing is $7488 \mathrm{~m}^{2}$ and is located about $500 \mathrm{~m}$ from the nearest watercourse. Domestic waste is transferred to a ditch system 
and the yard drains over ground to the same ditch. Farmyard manure (of which $\sim 850 \mathrm{t}$ is produced annually) is stored for extended periods of up to 1 year on a heap in the field. In total, $1076 \mathrm{~m}$ of farm tracks are situated within the farm boundary. The farm has 145 head of cattle which during grazing contribute approximately $6.8 \times 10^{13} \mathrm{E}$. coli to land per annum (an order of magnitude less than that associated with Farm C and W). Land application of FYM is made approximately 10 times a year at a rate of $4 \mathrm{tha}^{-1}$ but contributes negligible viable $E$. coli because of the extensive manure storage time.

\subsubsection{Farm C}

Farm $\mathrm{C}$ is a 178 ha dairy farm. The farmer has insufficient labour to manage his enterprise effectively and the level of debt significantly effects business decisions. The farmer has joined up to 'entry level stewardship' but has never received any grant aid for waste management. The farmer is aware of his responsibilities under cross compliance but he has never heard of the term 'diffuse pollution'. He left school before completing secondary school education, and he has some modest formal training in land and livestock management. He has not been exposed to new ideas by way of participating in professional discussion groups but does belong to the Dairy Farm Assurance Scheme. The enterprise is located in a gently undulating landscape and has several streams running through it, as well as a spring. The land is relatively free draining and there is no obvious evidence of soil compaction. The hard standing is $14433 \mathrm{~m}^{2}$ and is located about $250 \mathrm{~m}$ from the nearest watercourse. The yard drains underground to a stream. The farm disposes of its domestic waste water through a 100 yr old septic tank and soak-away in a field. The enterprise produces $\sim 400$ tonnes of solid manure annually, which is either stored in the farm buildings or uncovered on a heap in the field. Nearly $1.5 \mathrm{Ml}$ of dirty water is produced annually. This is held in an earth bank lagoon, which has $\sim 1$ month's storage. Livestock drink from and regularly cross the stream. Farm tracks total $680 \mathrm{~m}$ in length across the farm area. The farm has 400 dairy cattle and 35 calves, generating approximately $4 \mathrm{Ml}$ of slurry annually, which is stored in an additional earth banked slurry store. The farmer makes over 40 applications of slurry to land per year 
distributing in the region of $6.1 \times 10^{13}$ E. coli to land per annum. Grazing livestock in comparison contribute in the region of $2.01 \times 10^{14} \mathrm{E}$. coli to land per annum.

\subsubsection{Farm $W$}

Farm W is a 53 ha suckler beef and sheep enterprise partially located within Dartmoor National Park. The farm is a recent entrant into environmental stewardship and recently received a large grant to construct a covered dung store. While this farmer is struggling to remain economically viable under present market conditions he does have sufficient labour to manage his farm effectively. The farm carries some debt but this does not greatly on management decisions. The farmer did not complete secondary school and has no formal training in land and livestock management. He does not belong to any quality assurance scheme and has never participated in any professional discussion groups to improve the way he manages his enterprise. The farmer is aware of his responsibilities under cross compliance but has never heard of advisory information relating to soil and water management or heard of the term diffuse pollution. The farm landscape is slightly sloping and has streams running through it. Unlike the other two case study farms the shape of the fields are typically convex. The land is heavy but free from compacted soil. The landscape is supported by a network of drains which were installed fairly recently and function effectively. The area of the hard standing is $4754 \mathrm{~m}^{2}$ which drains either overground to a stream or into the domestic waste water system. The domestic waste water is disposed of through a recently installed biofilter system. The nearest watercourse is less than $50 \mathrm{~m}$ from this area. The enterprise produces about $440 \mathrm{t}$ of solid manure annually and the covered manure storage facilities are adequate in their capacity. Grazing cattle have access to a watercourse for drinking and they cross these areas regularly. A total length of track of $230 \mathrm{~m}$ is distributed across the farm. The farmer has 75 head of beef, and 400 sheep/lambs. Manures are typically spread between January and May, and November and December each year, accounting for an input of around $3.1 \times 10^{13} \mathrm{E}$. coli to land per year. The grazing livestock contribute approximately $4.6 \times 10^{14} \mathrm{E}$. coli to land per year. 


\subsection{Microbiological sample collection}

Microbiological water quality monitoring was undertaken on Farm A, C and W to provide a preliminary dataset against which to compare the resulting farm risk polygons. These three farms were chosen because we were able to locate sampling points representative of farm losses and free of upstream sources. Fortnightly samples were collected from each farm through the course of 2006. Stream discharge (Q) measurements were completed at each farm to obtain FIO flux data. Stream Q was estimated using the area-velocity method (Fetter, 2001). Flow velocity was measured using a Valeport model 002 open channel flow meter (Valeport Ltd., UK). The cross sectional area of the stream as a function of water level was determined and a rating equation derived to describe the stage-discharge relationship (Knighton, 1998). A rating curve approach was used because the streams were too small to set up fixed gauging stations. Water samples were collected in pre-sterilized 500-ml, screw top polypropylene bottles, stored on ice in a cool box and analyzed in the laboratory within 6 hr of collection. Standard methods of membrane filtration were used to determine bacterial concentrations in water (Anon, 2002).

\subsection{Statistical analysis}

Microbial data were log transformed and statistical analysis was performed using these transformed data. Comparison of microbial data was made using one-way ANOVA. The normal distribution of the log transformed data was checked by assessment of probability plots and Bartlett's test used to confirm homogeneity of variance.

\section{Results}

Each farm storyboard is translated into an overall risk classification based on the four risk criteria and is depicted visually to communicate where burdens of risk are greatest. Results (e.g. coordinates) for 31 participating farms are listed in Table 4. Example visual output from 
the toolkit for the first 9 of the farms studied, in the form of farm risk polygons, is shown in Figure 3. The plotted co-ordinates of the farm risk polygon (equivalent to risk score) correspond to the risk category attributed to each farm. Of the 31 farms assessed, $0 \%$ were categorised as negligible risk, $32 \%$ low, $65 \%$ medium, $3 \%$ high, and $0 \%$ very high risk.

Insert Table 4 and Fig 3

Specifically, Farm A, C and $\mathrm{W}$ resulted in a low, medium and high risk classification, respectively (with scores of 37, 47 and 65\%, respectively). For Farm A the process of risk classification suggests clearly that the issue of $E$. coli burden is relatively insignificant in this case due to extended storage period of FYM and relatively low livestock faecal inputs. Issues of obstacles, transfer, and perhaps most significantly infrastructure (e.g. farmyard drainage) would have warranted closer inspection with regards to mitigation had the E. coli burden posed a larger risk. In contrast, the overall narrative for Farm $\mathrm{C}$ translates into a medium risk categorization. Again the process suggests that it is in the context of infrastructure that the burden of risk is greatest (e.g. poor manure storage facilities and dirty water contamination on the farmyard), with some significant contributions to riskiness shaped by obstacles to taking action and issues of E. coli burden. Finally, the overall narrative for Farm W translates into a high risk categorization. Here it is issues of E. coli burden that are most problematic, (particularly due to the large number of sheep which are high E. coli shedding animals), but with significant burdens of risk linked to all four criteria. For Farms A, C and W, the farm risk polygons shown in Figure 3 can be associated with in-stream FIO data collected prior to export from the farm from fixed monitoring points during the 1 year sampling period (Figure 4). Box and whisker plots show the moments of the statistical distribution of FIO flux on Farm A, C and $\mathrm{W}$ throughout the annual sampling period. Fluctuations in FIO flux were apparent throughout the year. For Farm A, measured flux on sampling dates ranged between $\log _{10} 0.47$ and $\log _{10} 3.13 \mathrm{CFU}{ }^{-1} \mathrm{~s}^{-1}$. On Farm $\mathrm{C}$, the range in FIO loads was of a higher magnitude $\left(\log _{10} 3.09\right.$ to $\left.\log _{10} 4.98 \mathrm{CFU}^{-1} \mathrm{~s}^{-1}\right)$. Finally, Farm $\mathrm{W}$ had a range of FIO flux 
spanning $\log _{10} 3.36$ through to $\log _{10} 6.33 \mathrm{CFU} ~^{-1} \mathrm{~s}^{-1}$. One-way ANOVA confirmed that there was a significant difference between the loads from three farms that were monitored for microbial water quality. Further tests identified that Farm A exported significantly $(\mathrm{P}<0.0001)$ lower loads of E. coli than that associated with Farm C and W. There was no significant difference $(\mathrm{P}>0.05)$ between Farm $\mathrm{C}$ and $\mathrm{W}$.

Insert Fig 4

\section{Discussion}

Effective and pragmatic approaches to tackling microbial pollution from agriculture at the farm scale require identification and understanding of: (i) critical source areas (CSAs) of FIO loss; and (ii) management strategies to reduce risk. Any strategic risk assessment toolkit must therefore capture the interplay and importance of different farm scale elements in order to identify where mitigation might be made to constrain FIO loss from land to water to best effect. The cross-disciplinary toolkit is an approach that embodies a complex adaptive systems way of thinking whereby research, and evidence-based policy too, shifts from a command and control mentality to dealing with unpredictable systems through integrating diverse knowledge inputs into the process (Stringer et al., 2006; Macleod et al., 2007). The cross-disciplinary toolkit highlighted that changing farmer attitudes to manure and land management is part of this process by which we can make our food and water safer, but that changing attitudes is not always enough. Appreciation of this dynamic interplay of social and natural processes at the farm scale and understanding this interaction will allow the policy community not only to target high risk areas, but also develop mitigation strategies that are sensitive to the different ways in which risk is produced. Johnson et al (2008) argue that decisions on how to manage water quality could be based on private, social or ecological considerations depending on specific management goals and our toolkit is one such mechanism by which to apportion such considerations. 
The toolkit operates at the farm scale and the risk categorisation of each farm is derived with respect to the likelihood of FIO contamination impacting on a receptor - in this case surface waters. The approach demonstrates considerable compatibility with prevailing approaches to environmental risk management, most notably the source-pathway-receptor model (e.g. Lytton et al, 2003). In the case of the cross-disciplinary toolkit the magnitude of the E. coli burden (source) is assessed in relation to factors (landscape, infrastructural and human management related) that promote subsequent burden movement and delivery (via pathways) to surface waters (the receptor). This toolkit attempts to prioritise targeting of mitigation efforts within source, transfer, infrastructure or management related areas. Consequently, mitigation does not necessarily only need to take the form of physical changes in infrastructure or landscape, but instead can be instigated through programmes of debt management or accreditation in training to complement more traditional mitigation approaches such as those outlined in Oliver et al. (2007). Thus, the four axis approach suggests that, if a given farm had a large E. coli burden but the landscape features translated to minimal transfer potential then minimal risk would transpire. However, the four axis approach allows for a source to be problematic if infrastructure is an issue irrespective of runoff potential because of alternative transfer mechanisms relating to farmyard drainage and linking farm tracks which may operate as rapid conduits of FIO transfer. So it follows that a high E. coli source area will be cancelled out if it is located within a landscape of low transfer risk (e.g. the landscape acts as a 'safety-net'), but infrastructural controls will also play a bearing and should be consulted as a third risk criterion allowing for connectivity via artificial routes in the landscape (Edwards et al., 2008; Edwards and Hooda, 2008). Similarly, the degree to which obstacles prevent a farmer from taking action to limit pollution are accounted for within the framework.

Monaghan et al. (2008) suggest that the most effective mitigation strategies are those that address the main sources of contaminants within a system such as the use of advanced pond systems. Of course the human dimension must also be factored in to gain an appreciation that 
while infrastructure may be advantageous for limiting FIO loss from land to water, poor management can over-ride its intended benefits. Management decisions governing distribution of animal manures are critical social processes that vary in space and time and disproportionality occurs when inappropriate social actions occur in vulnerable biophysical settings (Nowak et al., 2006). This concept applies in reverse also; one farmer interviewed in our study had an astute awareness of diffuse pollution and stated: 'diffuse pollution - that's insidious pollution coming from unidentifiable sources'. While this farmer demonstrated understanding of environmental contamination issues, the landscape and farm enterprise, through no fault of his own, conspired against him, predominantly due to the steeply sloping clay soils and large number of high-shedding sheep and lambs increasing the transfer and burden related risks, respectively. As noted by Fischer et al. (2005), the adoption of crossdisciplinary research paradigms may offer the most relevant approach to developing solutions to real world problems.

Theoretically, we would have anticipated that each of the three monitored farms would be linked to significantly different E. coli fluxes because of the contrast in risk class associated with each farm. However, during 2006 annual rainfall for the south west of England was 1129 $\mathrm{mm}$ (The Met Office, 2007), 7\% lower than the 1961-1990 long term average. The load exported from Farm A was particularly low due to the low flow characteristics of the sampling location given this low rainfall. Microbial data presented within this evaluation therefore represented the results from a particularly dry year during which storm flow events were scarce at the sampling sites. The toolkit was used to identify potential risk of farms contributing FIOs to water, but for potential diffuse risk to become an actual risk, rainfall is needed to act as a driving mechanism (though large volumes of wash water are used twice a day on dairy farms and so some point sources can be independent of rainfall). We can speculate that had we obtained high flow event data, then the E. coli loads may have been several orders of magnitude higher than those reported (McDonald and Kay, 1981; Kay et al., 
2008b). Similarly, the range of flux data for both farms shown in Figure 2 would probably have been much larger if wet weather had predominated.

It is evident that farmers deal with 'risk' on a daily basis and that clearly they can be categorised as 'risk managers'. As such, farmers need to have access to, and accept and understand information about the microbial risks associated with farming practices. Our proposed toolkit is a mechanism through which we can combine risk assessment with risk communication. Therefore, not only does the toolkit integrate natural and socio-economic risk factors in its assessment of risk, but it also operates as an easy-to-use tool for communicating, in a visual manner, the output of actual risk assessment to real end-users e.g. farmers or 'risk managers'. As noted by van Wyk et al., (2008), decision makers are often overloaded with information and so there is an increased demand for tools that are credible yet simple.

Not all risk factors within the four risk criteria can be modified via a mitigation approach. Thus in the context of 'E. coli burden' it is reasonable to claim that changes could be made to livestock numbers, livestock type, spreading rates and spreading times as strategies to reduce farm scale risk. In the context of 'landscape transfer potential' it may be impossible to change slope, curvature or soil type but it may be possible to alter drainage and compaction to limit farm scale risk. In terms of issues of 'Infrastructure' it is perhaps unrealistic to consider mitigation in the form of changing farmyard area and farm track coefficient but it is hypothetically possible to make interventions in farmyard drainage and roofing, storage capacity and facilities, domestic wastewater treatment, gateway location and livestock access as a means of mitigating FIO loss from farms (e.g. via capital grant schemes for eligible farms [Natural England, 2008]). All risk factors linked to 'obstacles to taking action' could be targeted for risk alleviation to some extent. In essence this sense in which it is not possible to alter some aspects of farm riskiness means that all farms will have a baseline level of risk which cannot be reasonably overcome, and indeed which may form the basis for a hypothetical 'target' polygon based on assessments of cost-effectiveness (e.g. Brouwer and de 
Blois, 2008; Zaidi et al., 2008). Finally, there is likely to be a degree of interdependency between risk factors used in the toolkit. Therefore, with continued evolution of this prototype approach it would be wise to undertake a full sensitivity analysis to determine the sensitivity of the toolkit output to changes in individual risk factors.

\section{Conclusion}

Embracing a cross-disciplinary approach to farm FIO risk assessment allowed for an holistic evaluation of both landscape features and FIO sources in relation to land-owners capacities, knowledges and responsibilities to protect watercourses. The inclusion of both physical and socio-economic risk factors extends the range of mitigation strategies available and reinforces the advantages of coupling both natural and social sciences in farm-scale risk assessments. As our empirical evidence-base grows we can develop the toolkit so that it evolves from a 'device-to-aid-thinking' into a more robust component of a quantitative risk assessment approach. As an example, we acknowledge that not all E. coli burden to land is of equal mobility and there is clear potential to accommodate 'risk filters' so as to account for different levels of likely mobilisation and release of FIOs from the suite of faecal matrices encountered in the agricultural environment. This cross-disciplinary toolkit represents a first approximation of a combined approach to risk assessment and communication and offers a straightforward mechanism of accounting for the main risk drivers of FIO loss from farm enterprises whilst also appreciating decision-making constraints. Further testing using a larger programme of monitored farms will provide additional qualitative and quantitative validation and enhance our understanding of the toolkit's capabilities.

\section{Acknowledgements}

The authors would like to acknowledge the participation of the 28 anonymous experts for their valuable contributions in the risk factor weighting exercise and the farmers who allowed access to their land and provided valuable cooperation during farm audits and management interviews. We are also grateful to Dr Trevor Page for his help with Matlab coding and 
appreciate the valuable and constructive comments made by the Associate Editor and two anonymous referees. This work was funded as part of project RES-224-25-0086 by the Rural Economy and Land Use (RELU) programme who receive financial support from the Biotechnology and Biological Sciences Research Council (BBSRC), the Natural Environment Research Council (NERC), the Economic and Social Research Council (ESRC), the Department for Environment, Food and Rural Affairs (Defra) and the Scottish Office.

\section{References}

Anonymous. 2002. The Microbiology of Drinking Water Part 4 - A method for the isolation and enumeration of coliform bacteria and E. coli. The Environment Agency, UK.

Avery, S. M., Moore, A., and Hutchison, M. L., 2004. Fate of Escherichia coli originating from livestock faeces deposited directly onto pasture. Lett. Appl. Microbiol. 3, 355359.

Brouwer, R. and de Blois, C., 2008. Integrated modelling of risk and uncertainty underlying the cost and effectiveness of water quality measures. Environ. Model. Software 23, 922-937.

Burton, R.J.F., and Wilson, G.A., 2006. Injecting social psychology theory into conceptualisations of agricultural agency: Towards a post-productivist farmer selfidentity? J. Rural Studies 22, 95-115.

CEC, 2000. Council of the European Communities. Council Directive 200/60/EC of the European Parliament and of the council of 23 October 2000 establishing a framework for community action in the field of water policy. Official Journal of European Union L327, 1-72.

CEC, 2006. Council Directive 2006/7/EC of the European Parliament and of the council of $15^{\text {th }}$ February 2006 concerning the management of bathing water quality and repealing Directive 76/160/EEC. Off. J. European Union. L64, 37-51.

Chadwick, D., Fish, R., Oliver, D. M., Heathwaite, L., Hodgson, C., and Winter, M., 2008. Management of livestock and their manure to reduce the risk of microbial transfers to 
water - the case for an interdisciplinary approach. Trends Food Sci. Tech. 19, 240247.

Chambers B. J., Nicholson, R. J., Smith, K., Pain, B. F., Cumby, T. R., and Scotford, I. M., 2001. Managing Livestock Manures: Booklet 2 - Making better use of livestock manures on grassland. 24 pp. Defra, Noble House, Smith Square, London SW1P 3JR.

Cornelissen, A.M.G., van den Berg J., Koops W.J., Kaymak, U., 2003. Elicitation of expert knowledge for fuzzy evaluation of agricultural production systems. Agric. Ecosyst. Environ. 95, 1-18.

Defra 2003. Manure management plan: a step by step guide for farmers. Viewed on $12^{\text {th }}$ October 2008. Available online at: http://www.defra.gov.uk/corporate/regulat/forms/agri env/nvz/manureplan.pdf

Defra 2005. Producing a soil management plan for environmental stewardship. Viewed on $12^{\text {th }}$ October 2008. Available online at: http://www.defra.gov.uk/erdp/pdfs/es/guidance/es-soil-management-plan.pdf

Duffy, G, Lynch, O. A. and Cagney, C., 2008. Tracking emerging zoonotic pathogens from farm to fork. Meat Science 78, 34-42.

Edwards, A. C. and Hooda, P. S., 2008. Farmyard point discharges and their influence on nutrient and labile carbon dynamics in a second order stream draining through a dairy unit. J Environ. Manage. 87, 91-99.

Edwards, A. C., Kay, D., McDonald, A. T., Francis, C., Watkins, J., Wilkinson, J. R. and Wyer, M. D., 2008. Farmyards, an overlooked source for highly contaminated runoff. J Environ. Manage. 87, 51-59

Fetter, C.W. 2001. Applied Hydrogeology. 4th ed. New Jersey: Prentice Hall. 598 p.

Fischer, A. R. H., de Jong, A. E. I., de Jonge, R., Frewer, L. J., and Nauta, M. J., 2005. Improving food safety in the domestic environment: the need for a transdisciplinary approach. Risk Analysis 25, 503-514. 
Fish, R., Winter, M., Oliver D. M., Chadwick, D., Selfa, T., Heathwaite, L., Hodgson, C. (submitted). Unruly pathogens? Eliciting values for environmental risk in the context of heterogeneous expert knowledge Environmental Science and Policy

Goss, M and Richards, C., 2008. Development of a risk-based index for source water protection planning, which supports the reduction of pathogens from agricultural activity entering water resources. J Environ. Manage. 87, 623-632.

Havelaar, A. H., Braunig, J., Christiansen, K., Cornu, M., Hald, T., Mangen, M. J. J., Molbak, K., Pielaat, A., Snary, E., Van Pelt, W., Velthuis, A. and Wahlstrom, H. 2007. Towards an integrated approach in supporting microbiological food safety decisions. Zoonoses Pub. Health, 54, 103-117.

Heathwaite, L., Sharpley, A. and Bechmann, M., 2003. The conceptual basis for a decision support framework to assess the risk of phosphorus loss at the field scale across Europe. J. Plant Nutr. Soil Sci. 166, 447-458.

Hodgson, C.J., Bulmer N. and Chadwick D.R. 2008 The survival of Faecal Indicator Organisms (FIOs) in soil, following dairy cattle slurry application to land by surface broadcasting and shallow injection. In; Potential for simple technology solutions in organic manure management. Proceedings of the $13^{\text {th }}$ RAMIRAN International Conference, Albena, Bulgaria June 2008. ISBN 978-954-9057571-6-3182-187.

Johnson, E. K., Moran, D. and Vinten, A. J. A., 2008. A framework for valuing the health benefits of improved bathing water quality in the River Irvine catchment. J Environ. Manage. 87, 633-638.

Kay, D., Crowther, J., Fewtrell, L., Francis, C. A., Hopkins, M., Kay, C., McDonald, A. T., Stapleton, C. M., Watkins, J., Wyer, M. D., 2008a. Quantification and control of microbial pollution from agriculture: a new policy challenge? Environ. Sci. \& Policy $11,171-184$.

Kay, D., Crowther J., Stapleton, C. M., Wyer, M. D., Fewtrell, L., Anthony, S., Bradford, M., Edwards, A., Francis, C. A., Hopkins, M., Kay, C., McDonald, A. T., Watkins, J. and 
Wilkinson, J., 2008b. Faecal indicator organism concentrations and catchment export coefficients in the UK. Water Res. 42, 2649-2661.

Kay, D., Edwards, A. C., Ferrier, R. C., Francis, C., Kay, C., Rushby, L., Watkins, J., McDonald, A. T., Wyer, M., Crowther, J. and Wilkinson, J., 2007. Catchment microbial dynamics: the emergence of a research agenda. Prog. Phys. Geog. 31, 5976.

Knighton, D. 1998. Fluvial forms and processes: a new perspective. Arnold, London.

Lytton, L., Howe, S., Sage, R. and Greenaway, P., 2003. Groundwater abstraction pollution risk assessment. Water Sci. Tech. 47, 1-7.

Macleod, C. J. A., Scholefield, D and Haygarth, P. M., 2007. Integration for sustainable catchment management. Sci. Total Environ. 373, 591-602.

MAFF. 1998. Code of Good Agricultural Practice for the Protection of Water (The Water Code). Ministry of Agriculture, Fisheries and Food. London, UK.

McDonald, A., and Kay, D. 1981. Enteric bacterial concentrations in reservoir feeder streams: baseflow characteristics and response to hydrograph events. Water Res. 15, 861-868.

Monaghan, R. M., de Klein, C. A. M., and Muirhead, R. W., 2008. Prioritisation of farm scale remediation efforts for reducing losses of nutrients and faecal indicator organisms to waterways: a case study of New Zealand dairy farming. J Environ. Manage. 87, 609622.

Morris, D. G. 1999. Sub-set of UK time-series of monthly rainfall grids. NERC, Institute of Hydrology, Wallingford.

Muirhead, R. W., Collins, R. P., and Bremer, P. J. 2005. Erosion and subsequent transport state of Escherichia coli from cowpats. Appl. Environ. Microbiol. 71, 2875-2879.

Natural England 2008. England Catchment Sensitive Farming Capital Grant Scheme 2008/2009 Farmer Handbook. Available online at: http://www.defra.gov.uk/farm/environment/water/csf/pdf/CSF3\%2008.pdf $\left(\right.$ on $12^{\text {th }}$ October 2008). 
Nicholson, F. A., Groves, S. J. and Chambers, B. J., 2005. Pathogen survival during livestock manure storage and following land application. Biores. Tech., 96, 135-143.

Nowak, P, Bowen, S., and Cabot, P. E., 2006. Disproportionality as a framework for linking social and biophysical systems. Soc. Nat. Res., 19, 153-173.

Oliver, D. M., Heathwaite, A. L., Hodgson, C. J. and Chadwick, D. R., 2007. Mitigation and current management attempts to limit pathogen survival and movement in farmed grasslands. Adv. Agron., 93, 95-152.

Refsgaard, J. C., van der Sluijs, J. P., Hoberg, A. L., and Vanrolleghem, P. A., 2007. Uncertainty in the environmental modelling process - a framework and guidance. Environ Model. Software 22, 1543-1556.

Smith, K. A., Brewer, A. J., Crabb, J and Dauven, A., 2001. A survey of the production and use of animal manures in England and Wales. III. Cattle manures. Soil Use Manage. $17,77-87$.

Strachan, N. J. C., Dunn, G. M., Locking, M. E., Reid, T. M. S. and Ogden, I. D., 2006. Escherichia coli O157: burger bug or environmental pathogen? Int. J. Food Microbiol., 112, 129-137.

Stringer, L. C., Dougill, A. J., Fraser, E., Hubacek, K., Prell, C. and Reed, M. S., 2006. Unpacking 'participation' in the adaptive management of social-ecological systems: a critical review. Ecol. Soc. 11, 39 (online).

The Met Office, 2007. http://www.metoffice.gov.uk/climate/uk/2005/seasonal.html Accessed 12th October 2008.

vanWyk, E., Roux, D. J., Drackner, M. and McCool, S. F., 2008. The impact of scientific information on ecosystem management: making sense of the contextual gap between information providers and decision makers. Environ. Manage. 41, 779-791.

Vinten, A. J. A., Sym, G., Avdic, K., Crawford, C., Duncan, A. and Merrilees, D. W., 2008. Faecal indicator pollution from a dairy farm in Ayreshire, Scotland: source apportionment, risk assessment and potential of mitigation measures. Water Res 42 , 997-1012. 
Vinten, A. J. A., Douglas, J. T., Lewis, D. R., Aitken, M. N., and Fenlon, D. R., 2004.

Relative risk of surface water pollution by $E$. coli derived from faeces of grazing

animals compared to slurry application. Soil Use Manage. 20, 13-22.

Weaver, R. W., Entry, J. A. and Graves, A., 2005. Numbers of fecal streptococci and

Escherichia coli in fresh and dry cattle, horse, and sheep manure. Can. J. Microbiol.

$51,847-851$.

White, S. L., Sheffield, R. E., Washburn, S. P., King, L. D., and Green, J. T., 2001. Spatial and time distribution of dairy cattle excreta in an intensive pasture system. J. Environ. Qual. 30, 2180-2187.

Zaidi, A. Z., deMonsabert, S. M., El-Farhan, R., 2008. How to include economic analysis in TMDL allocation. J. Wat. Res. Plan. Manage. 134, 214-223.

\section{List of Figure captions}

Figure 1: Four-axis framework of the toolkit and visualisation of FIO loss risk on a hypothetical farm.

Figure 2: Example output from the E. coli burden to land assessment for a dairy farm surveyed in the study. E. coli burden to land - is designed to incorporate into the toolkit the FIO risks that arise from the application and deposition of manures and faeces during farming activities. It is not spatially explicit but represents all E. coli inputs to land within the farm boundary. The burden profile is derived using livestock type and number, excretion rates, dieoff coefficients (as per seasonal differentiation), grazing duration (in this case April through September), manure application timings and rates. Total E. coli burden is the sum of grazing inputs and slurry application inputs across the whole farm. In this example slurry is applied weekly but the scale of operation does not allow for differentiating which fields have had manure applied.

Figure 3: Farm risk polygons for nine of the 31 farms assessed in the Taw catchment, Devon. Number in centre of polygon reflects polygon risk score. Polygon colour reflects risk categorisation $[$ green $=$ low, orange $=$ medium and red $=$ high risk $]$

Figure 4: Farm risk polygons for Farm A, C and W and associated box and whisker plots showing moments of the statistical distribution of FIO flux on respective farms throughout annual sampling period. [Horizontal 'dash' = median, box represents inter-quartile range, whisker represents upper and lower limits]. 


\section{Obstacles}

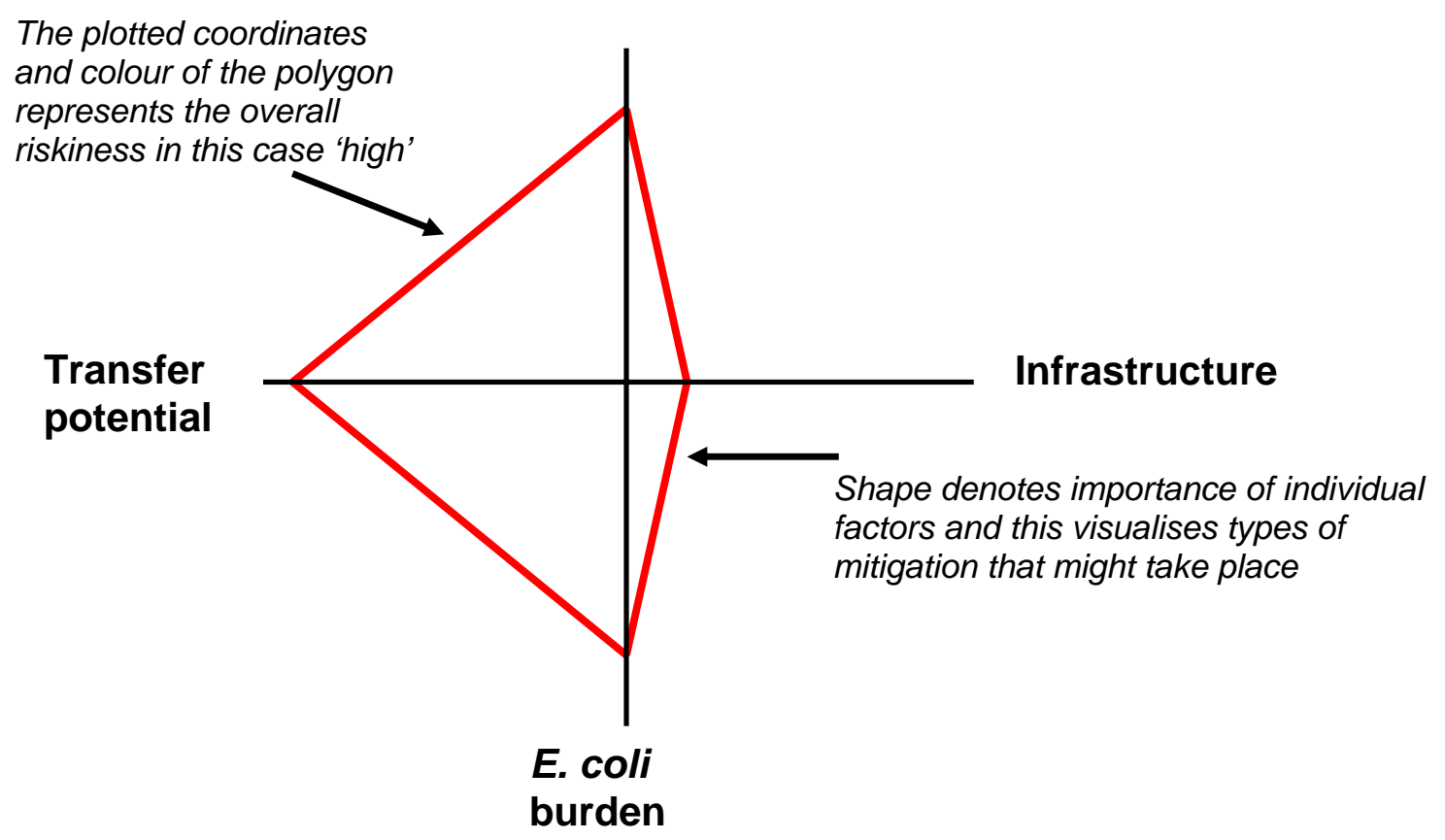

Figure 1: 


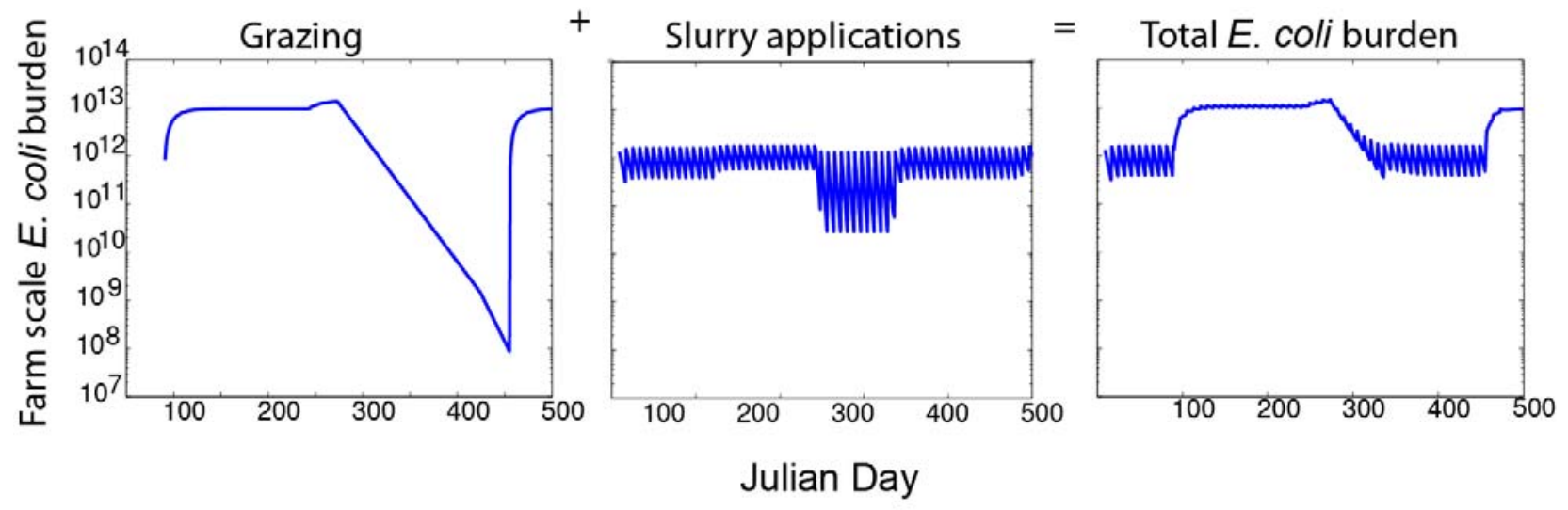

Figure 2: 


\section{Farm S}

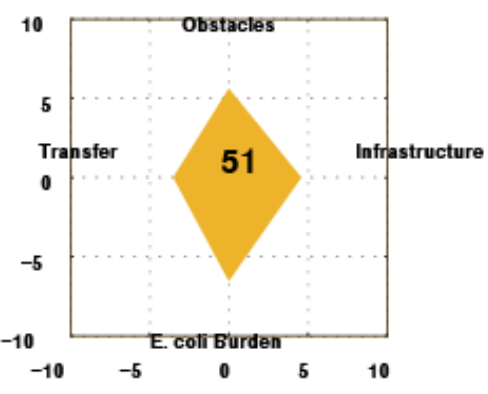

Farm A

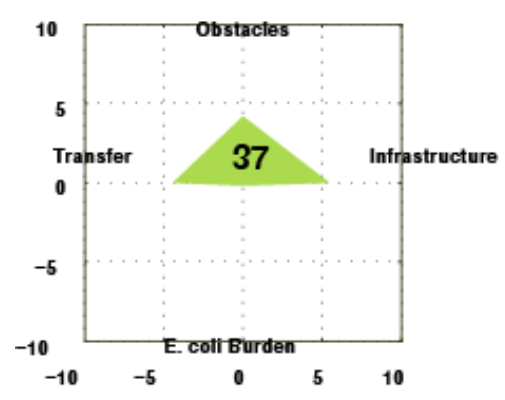

Farm HC

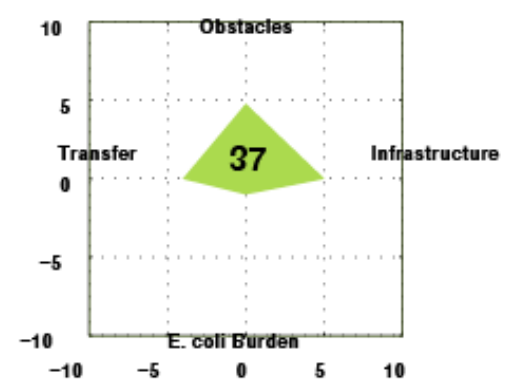

Farm BH

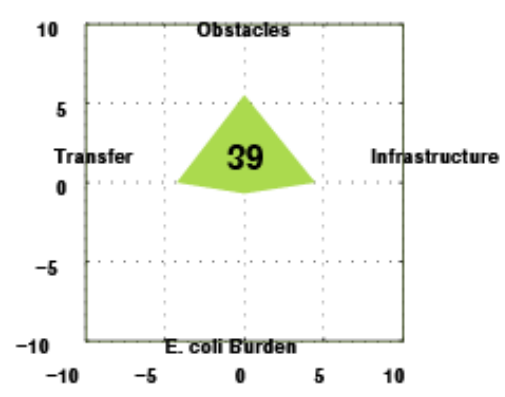

Farm M

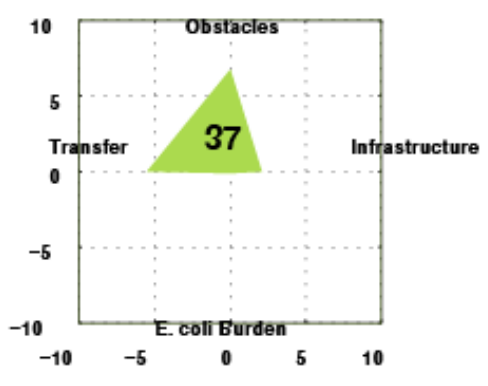

Farm W

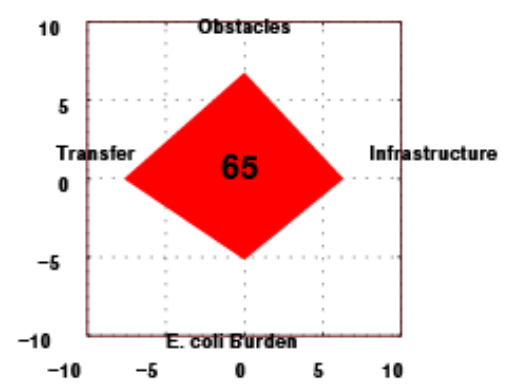

Farm B

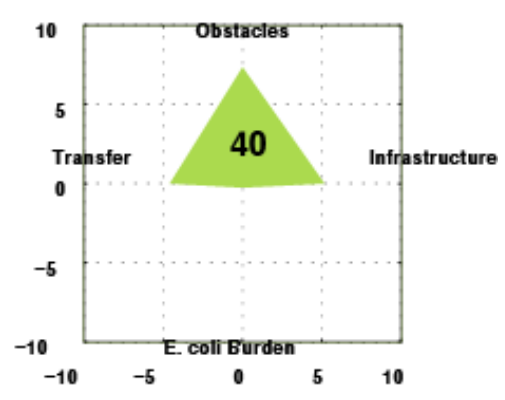

Farm MN

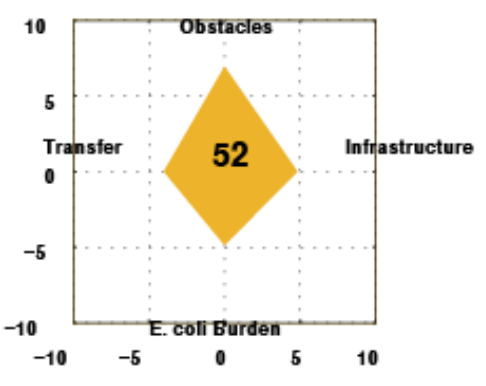

Farm C

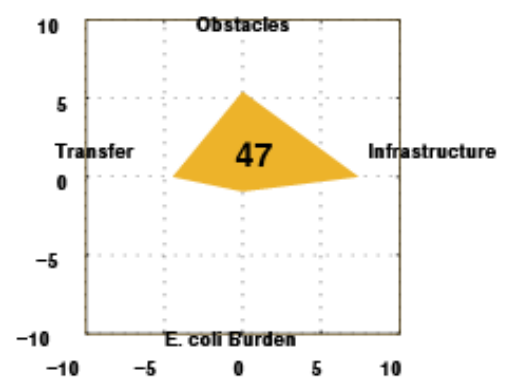

Figure 3: 
Farm A
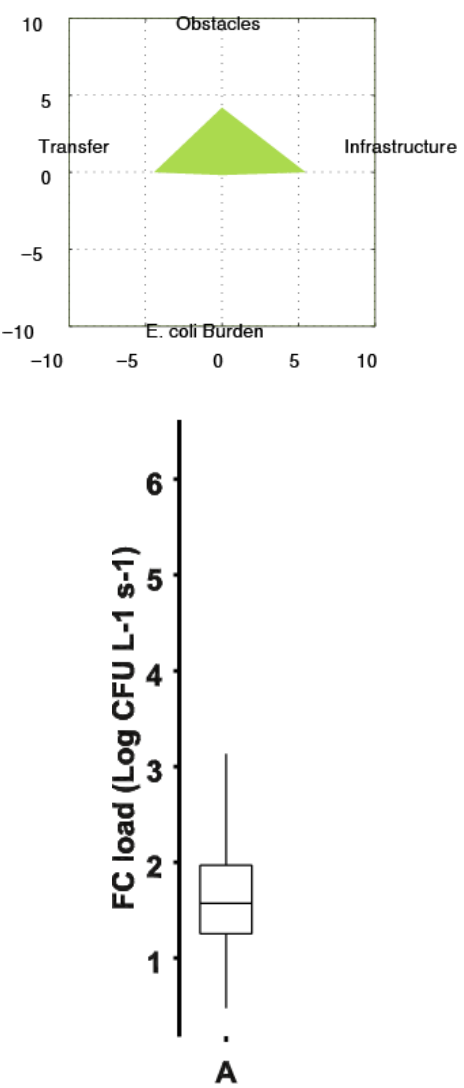

Farm C
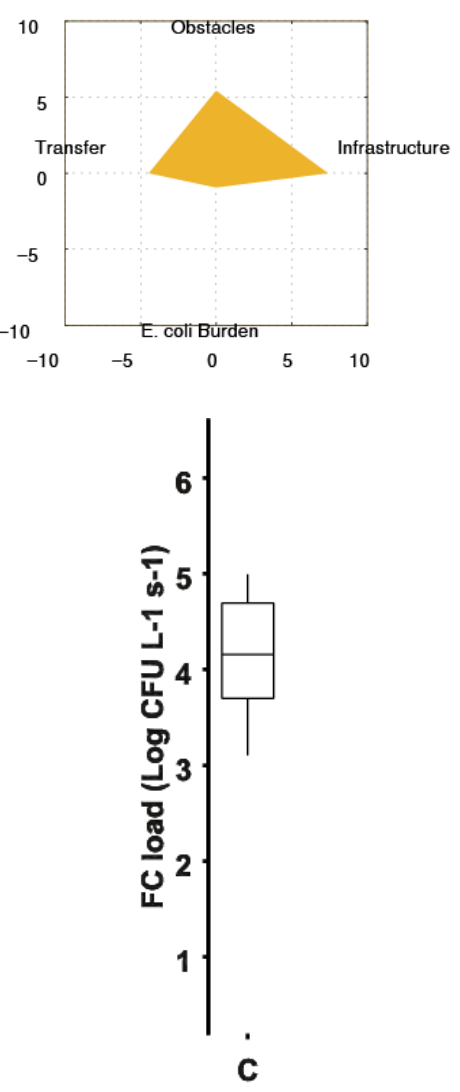

Farm W
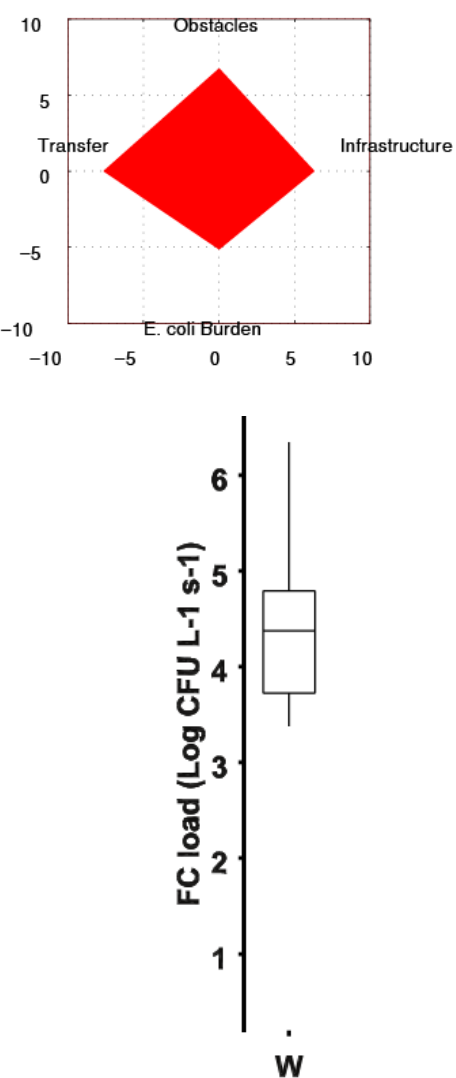

Figure 4: 
Table 1: Risk factors associated with four over-arching risk criteria of farm-scale FIO loss from land to water (with sources of data used to populate the toolkit shown in parenthesis).

- Farmyard drainage (FS)

- Steading / yard area*(OS)

- Slurry storage capacity (FS)

- FYM storage facilities (FS)

- Domestic wastewater treatment (FS)

- Gateway location as promoter / preventer of field-to-field connectivity to watercourse (FS)

- Farm track co-efficient (extent of farm tracks across farm area) (OS)

- Livestock watercourse access for drinking (FS)

- Livestock watercourse access for fording/ crossing (FS)
- Receipt of technical grants (FS)

- Influence of debt (FS)

- Sufficiency of farm labour force (FS)

- Level of participation in training, accreditation and learning networks (FS)

- Degree of understanding \& awareness of microbial risk discourses (FS)

- Presence of a regulatory environment (FS)

- Level of participation in agrienvironmental schemes (FS)

- Organic status (FS)

- Level of membership to quality assurance schemes (FS)

\section{Transfer potential}

- Averaged farm slope (5m DTM)

- Typical slope shape (convex / concave) (5m DTM)

- Dominant Soil type (Soil map records)

- Extent of soil compaction (FS)

- Artificial drainage (FS)

\section{E. coli burden to land $\left(\mathrm{ha}^{-1}\right)$}

- Livestock type (FS)

- Faecal inputs (Chambers et al., 2001)

- Grazing seasons and frequency of application (FS)

- Die-off rates (see Table 2)

- Farm area (OS)

FS: Farmer survey

OS: Digitised Ordnance Survey maps

5m DTM: 5m Digital Terrain Model (NextMap Britain)

* This includes all covered areas and buildings at the in the central farmyard area, not buildings included in distant fields 
Table 2: Parameters used within the toolkit E. coli burden model axis, and associated values (all rates and concentrations calculated from dry rate conversions).

\section{E. coli burden to land parameter}

Daily load of E. coli excreted by 1 dairy cow (cfu) ${ }^{3,5,6}$

Daily load of E. coli excreted by 1 beef cow (cfu) ${ }^{3,4}$

Daily load of E. coli excreted by 1 calf (cfu) ${ }^{3,4}$

Daily load of E. coli excreted by 1 sheep (cfu) ${ }^{3,4}$

Daily load of E. coli excreted by 1 lamb (cfu) ${ }^{3,7}$

Summer broadcast exponential decline rate $\left(\text { day }^{-1}\right)^{1}$

Autumn broadcast exponential decline rate $\left(\text { day }^{-1}\right)^{1}$

Spring broadcast exponential decline rate $\left(\text { day }^{-1}\right)^{1}$

November start date, exponential decline in bovine faeces (day $\left.{ }^{-1}\right)$ [winter \& autumn] ${ }^{2}$

November start date, exponential decline in ovine faeces (day ${ }^{-1}$ ) [winter \& autumn] ${ }^{2}$

Expert judged spring and summer bovine die-off $\left(\right.$ day $\left.^{-1}\right)$

Expert judged spring and summer ovine die-off $\left(\right.$ day $\left.^{-1}\right)$

Typical slurry decline rate over housed period $\left(\text { day }^{-1}\right)^{1}$

Initial slurry concentration in spring $\left(\mathrm{cfu} \mathrm{g}^{-1}\right)^{1}$

Initial slurry concentration in summer $\left(\mathrm{cfu} \mathrm{g}^{-1}\right)^{1}$

Initial slurry concentration in autumn $\left(\mathrm{cfu} \mathrm{g}^{-1}\right)^{1}$

Summer slurry dry matter content (\%) ${ }^{1}$

Autumn slurry dry matter content (\%) ${ }^{1}$

Spring slurry dry matter content (\%) ${ }^{1}$

Fresh FYM typical start concentration $\left(\mathrm{cfu} \mathrm{g}^{-1}\right)^{1}$

FYM die-off rate (generic, middle heap value) $\left(\text { day }^{-1}\right)^{1}$

FYM dry matter content (\%) ${ }^{1}$

\section{Value}

$8.99 \times 10^{8}$

$2.54 \times 10^{9}$

$2.10 \times 10^{10}$

$7.74 \times 10^{8}$

$1.01 \times 10^{10}$

$-0.5476$

$-0.2049$

$-0.2629$

$-0.0606$

$-0.0640$

$-0.0909$

$-0.0920$

$-0.0362$

126184

21849

140570

6.0

9.0

7.3

17819

$-0.100$

$\sim 21 \%$

${ }^{1}$ Taken from Hodgson et al. (2008) ${ }^{2}$ Taken from Avery et al., (2004), ${ }^{3}$ uses data from Chambers et al., (2001), ${ }^{4}$ uses data from Weaver et al., (2005), ${ }^{5}$ uses data from White et al., (2001), ${ }^{6}$ uses data from Muirhead et al. (2005), and ${ }^{7}$ uses data from Vinten et al. (2004) 
Table 3: Relative weight of influence on FIO risk loss from land to water associated with 'infrastructure', 'transfer potential' and 'obstacles to taking action' alongside characterisation of (and rationale for) risk magnitude attributed to farm circumstances

\begin{tabular}{|c|c|c|c|}
\hline $\begin{array}{l}\text { Axis and risk } \\
\text { factor }\end{array}$ & Weight & $\begin{array}{l}\text { Characterisation and } \\
\text { Scoring } \\
\text { (where } 1 \text { = Highest risk } \\
\text { and } 0 \text { lowest risk except*) }\end{array}$ & Rationale for first-approximation scoring system \\
\hline \multicolumn{4}{|l|}{ Infrastructure } \\
\hline $\begin{array}{l}\text { Farmyard } \\
\text { drainage }\end{array}$ & 0.72 & $\begin{array}{l}\text { DST }=0.1 / \text { DWT }=0.25 / \text { Slurry } \\
\text { store }=0.5 / \text { Underground to } \\
\text { stream }=0.9 / \text { Overground to } \\
\text { stream }=1.0\end{array}$ & $\begin{array}{l}\text { An overground drain to stream represents no appropriate drainage in place and therefore offers the least resistance of FIO transfer to } \\
\text { watercourse. Underground to stream increases the retention possibility of FIOs slightly. Drainage to slurry store increases volume of } \\
\text { slurry to spread to land, but it introduces a reservoir rather than direct transfer to watercourse so less risky than overground and } \\
\text { underground routes. Drainage to dirty water tank route is in similar vein to slurry store, but DW is less risky than slurry with respect to } \\
\text { FIO persistence. Domestic septic tank is the least direct route, therefore least risky. }\end{array}$ \\
\hline $\begin{array}{l}\text { Area of hard } \\
\text { standings }\left(\mathrm{m}^{2}\right)\end{array}$ & 0.55 & $\begin{array}{l}0=0 /<10000=0.2 /<20000=0.4 / \\
<30000=0.6 /<40000=0.8 / \\
>40001=1.0\end{array}$ & $\begin{array}{l}\text { Greater farmyard area provides increased impervious surface area and hub of livestock/manure activity. Increased farmyard area in } \\
\text { turn allows for increased potential for contaminated surface runoff from farm yard area. }\end{array}$ \\
\hline $\begin{array}{l}\text { Storage capacity } \\
\text { (slurry) }\end{array}$ & 0.62 & $\begin{array}{l}\text { not needed }=0 />6 \mathrm{mo}=0 / 5 \mathrm{mo}= \\
0.2 / 4 \mathrm{mo}=0.4 / 3 \mathrm{mo}=0.6 / 2 \mathrm{mo}= \\
0.8 / 1 \mathrm{mo}=1.0\end{array}$ & $\begin{array}{l}\text { Greater than } 6 \text { months storage is the least risky response as the farmer can store slurry during wet periods of the year preventing ill- } \\
\text { timed spreading. The risk increases with decline in slurry storage capacity. [note that catastrophic failure of slurry stores are not } \\
\text { included in this assessment] }\end{array}$ \\
\hline $\begin{array}{l}\text { Storage facilities } \\
\text { (FYM) }\end{array}$ & 0.45 & $\begin{array}{l}\text { farm building }=0.001 / \text { covered }= \\
0.25 . / \text { uncovered }=0.75 / \text { spread } \\
\text { straight to land }=1.0\end{array}$ & $\begin{array}{l}\text { Farm building storage allows for the FYM to be protected from rainfall and can therefore enhance composting. FYM Spread straight to } \\
\text { land represents the opposite and is regarded as highest risk option. Uncovered FYM in field is considered much more risky than } \\
\text { covered heaps on field because there is more chance for contaminated runoff following rainfall }\end{array}$ \\
\hline $\begin{array}{l}\text { Domestic } \\
\text { wastewater } \\
\text { treatment }\end{array}$ & 0.43 & $\begin{array}{l}\text { Biofilter }=0.001 / \text { DST }=0.25 / \\
\text { disconnected ditch }=0.75 / \\
\text { connected ditch }=1.0\end{array}$ & $\begin{array}{l}\text { Ditch systems of considerable risk compared to DST and biofilter systems because they have no real structure other than transferring } \\
\text { domestic waste via a channel to the environment. The DST and biofilter have system in place to attempt to retain FIOs and thus } \\
\text { enhance die-off over time. The biofilter is more protective than a standard septic tank due to technology improvements in design }\end{array}$ \\
\hline Gateway location & 0.39 & $\begin{array}{l}\text { Away from point of drainage }=0.1 / \\
\text { random }=0.5 / \text { Near point of } \\
\text { drainage }=1.0\end{array}$ & $\begin{array}{l}\text { Gateways located near a point of drainage allow for increased potential for field-to-field connectivity which may lead to watercourse. } \\
\text { The converse is true for gateways located away from point of drainage. }\end{array}$ \\
\hline $\begin{array}{l}\text { Farm track density } \\
\text { (farm area/ track } \\
\text { length) }\end{array}$ & 0.42 & $\begin{array}{l}\text { *Farm track coefficient (lower } \\
\text { number }=\text { worse) } \\
>1=0 / 0.9-1=1 / 0.8-0.9=2 / 0.7- \\
0.8=3 / 0.6-0.7=4 / 0.5-0.6=5 / \\
0.4-0.5=6 / 0.3-0.4=7 / 0.2-0.3= \\
8 / 0.1-0.2=9 /<0.1=10\end{array}$ & $\begin{array}{l}\text { The larger the area of farmed land per metre of farm track, the lower the risk because this implies less tracks are dissecting the farmed } \\
\text { land, reducing connectivity via track conduits. Larger area of farm per metre of farm track equates to larger coefficient (less risk). }\end{array}$ \\
\hline $\begin{array}{l}\text { Cattle drinking } \\
\text { access }\end{array}$ & 0.82 & No $=0.001 /$ Yes $=1.0$ & $\begin{array}{l}\text { Access equates to the potential for direct defecation in streams, any access for drinking is of equal risk as all allow for defecation input } \\
\text { whether access is restricted to } 1 \mathrm{~m} \text { or entire stream reach. Low risk appreciates that livestock may on occasion pass through fencing. }\end{array}$ \\
\hline Cattle fording & 0.82 & $\begin{array}{l}\text { No }=0.001 / \text { Yes weekly }=0.14 / \\
\text { Yes daily }=1.0\end{array}$ & $\begin{array}{l}\text { Daily crossing will allow for increased potential for direct defecation into stream whereas those farms where livestock fording is } \\
\text { prevented are not at risk from direct deposition.... weekly fording is } 1 / 7^{\text {th }} \text { the risk of daily crossing. }\end{array}$ \\
\hline \multicolumn{4}{|r|}{ 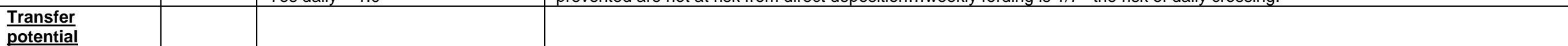 } \\
\hline $\begin{array}{l}\text { Average slope } \\
\text { angles }\end{array}$ & 0.73 & $\begin{array}{l}0-1 \text { degree }=1, / 1.1-2=2 / 2.1-3 \\
=3 \text { etc etc etc }\end{array}$ & Those farms with lower average slope angle across farm area are less likely to promote transfer via surface runoff processes \\
\hline $\begin{array}{l}\text { Average slope } \\
\text { shape }\end{array}$ & 0.73 & $\begin{array}{l}\text { Concave }=0.75 / \text { Covex }=1.0 / \\
\text { Mixed }=0.2\end{array}$ & $\begin{array}{l}\text { Convex slopes allow runoff to gain momentum with distance downslope thus increasing risk of delivery to streams at end of slope. In } \\
\text { contrast concave slopes allow runoff to lose momentum downslope and are therefore less risky (but still of some risk as ultimately } \\
\text { distance to watercourse after slope levels out will be important). Mixed slopes may allow for runoff to be trapped due to undulating }\end{array}$ \\
\hline
\end{tabular}




\begin{tabular}{|c|c|c|c|}
\hline & & & profile and therefore are of less risk than the concave only slopes but we cannot attribute zero risk to mixed slope \\
\hline $\begin{array}{l}\text { Dominant Soil } \\
\text { type }\end{array}$ & 0.73 & $\begin{array}{l}\text { Light }(\text { sandy })=0.1 / \text { medium }=0.5 / \\
\text { heavy }(\text { clay })=1.0\end{array}$ & $\begin{array}{l}\text { Heavy soils promote runoff and soil cracking and therefore rank as higher risk, light soils allow for infiltration and cell retention in the } \\
\text { soil matrix }\end{array}$ \\
\hline Soil compaction & 0.73 & no $=0 /$ yes $=1.0$ & Soil deformation promotes runoff \\
\hline Field drainage & 0.49 & $\begin{array}{l}\text { no }=0 / \text { yes but inefficient }=0.5 / \\
\text { yes \& efficient }=1.0\end{array}$ & $\begin{array}{l}\text { Assumption that drainage allows unimpeded subsurface transfer. Presence of drains are designated here as rapid conduits. If drains } \\
\text { are noted to be functioning inadequately these Inefficient drains as less of a subsurface transfer risk compared with efficient drainage } \\
\text { systems. }\end{array}$ \\
\hline \multicolumn{4}{|l|}{$\frac{\text { Obstacles to }}{\text { taking action }}$} \\
\hline $\begin{array}{l}\text { Receipt of } \\
\text { technical grants } \\
\text { for waste } \\
\text { management }\end{array}$ & 0.83 & Yes $=0 / \mathrm{No}=1$ & $\begin{array}{l}\text { Assumption that if farm has received external monies for the development of remedial waste measures then risk can be assumed to be } \\
\text { lower. }\end{array}$ \\
\hline Influence of Debt & 0.48 & $\begin{array}{l}\text { No/Negible }=0 / \text { Yes but } \\
\text { manageable }=0.5 / \text { Signifcantly } \\
\text { influences }=1\end{array}$ & $\begin{array}{l}\text { Works on the assumption that presence of debt is a control over potential investment decisions of which measures to reduce waste will } \\
\text { be indicative. Current assessment is based on a qualitative measure regarding how debt is perceived to affect effect enterprise } \\
\text { management. }\end{array}$ \\
\hline $\begin{array}{l}\text { Adequacy of } \\
\text { labour force } \\
\text { relative to scale } \\
\text { and intensity of } \\
\text { enterprise }\end{array}$ & 0.45 & $\begin{array}{l}\text { Highly sufficient }=0 / \text { Sufficient }= \\
0.25 / \text { Barely sufficent }= \\
0.75 / \text { Insufficient }=1\end{array}$ & $\begin{array}{l}\text { Works on the assumption that enterprise will be less able to deal with environmental externalities as human capital becomes more } \\
\text { 'stretched' to maintain viable production. Assessment is based on a four fold qualitative measure regarding perceived sufficiency of } \\
\text { labour force to manage enterprise effectively. }\end{array}$ \\
\hline $\begin{array}{l}\text { Level of training } \\
\text { and accreditation }\end{array}$ & 0.64 & Yes $=0 / \mathrm{No}=1$ & $\begin{array}{l}\text { Assumption that inclination to manage for environmental protection is raised by farmers' level of formal educational attainment in land } \\
\text { and livestock management. Currently no differentiation is made here between forms and extents of training/accreditation. }\end{array}$ \\
\hline $\begin{array}{l}\text { Level of } \\
\text { Participation in } \\
\text { Discussion } \\
\text { Groups }\end{array}$ & 0.61 & Yes $=0 / \mathrm{No}=1$ & $\begin{array}{l}\text { Assumption that inclination to manage for environmental protection is raised where farmers' participation level in networks of } \\
\text { professional self-learning. Currently no differentiation is made here between forms of participation }\end{array}$ \\
\hline $\begin{array}{l}\text { Degree of } \\
\text { understanding and } \\
\text { awareness of } \\
\text { microbial risk } \\
\text { discourses }\end{array}$ & 0.49 & $\begin{array}{l}\text { Aware and clear understanding }= \\
\text { O/aware but understanding unclear } \\
=0.5 / \text { Unaware }=1\end{array}$ & $\begin{array}{l}\text { Assumption that risks fall depending on levels of awareness of environmental risk categories (using diffuse pollution as indicator of } \\
\text { this). Distinction between awareness and understanding produces a three fold classification. Ability to verbally articulate meaning of } \\
\text { 'diffuse pollution' results in lowest risk. Farmers who are aware of this terminology but cannot articulate meaning considered lower risk } \\
\text { than those who are completely unaware of this 'key' policy signal. }\end{array}$ \\
\hline $\begin{array}{l}\text { Presence of a } \\
\text { regulatory } \\
\text { environment }\end{array}$ & 0.49 & Yes $=0 / \mathrm{No}=1$ & $\begin{array}{l}\text { Tries to build in a wider regulatory effect to an assessment of risk. Assumption is that a farmer's sense of responsibility will be } \\
\text { enhanced, however indirectly, by cultures of compliance existing within the farming industry. In our case all farmers are awarded this } \\
\text { low risk. }\end{array}$ \\
\hline $\begin{array}{l}\text { Level of } \\
\text { participation in } \\
\text { agri-environmental } \\
\text { scheme }\end{array}$ & 0.69 & $\begin{array}{l}\text { Yes }(\text { HLS })=0 / \text { YES }([0] E L S)= \\
0.5 / \text { No }=1\end{array}$ & $\begin{array}{l}\text { This is used as a signifier of endemic attitudes toward risk mitigation rather than forms of management practice. The argument is that } \\
\text { levels of participation are index of these attitudes. HLS represents lowest risk/ELS medium etc. }\end{array}$ \\
\hline Organic Status & 0.68 & Yes $=0$ Planned $=0.5 / \mathrm{No}=1$ & $\begin{array}{l}\text { Again used as a signifier of endemic attitudes toward risk mitigation. Argument is that OFs are likely to be more predisposed to taking } \\
\text { action. Distinctions are made between converts. }\end{array}$ \\
\hline $\begin{array}{l}\text { Membership of } \\
\text { quality assurance } \\
\text { scheme }\end{array}$ & 0.50 & Yes $=0 / \mathrm{No}=1$ & $\begin{array}{l}\text { Like above is used as a signifier of endemic attitudes towards risk mitigation rather than management practices per se. The argument } \\
\text { is that levels of participation are an index of these attitudes. No distinction is made between schemes. }\end{array}$ \\
\hline
\end{tabular}

DST = domestic septic tank, DWT = dirty water tank, ELS / HLS / OELS = entry level scheme, higher level scheme and organic entry level scheme for environmental stewardship, respectively. 
Table 4: Farm risk polygon co-ordinates (relative risk scores) for the four axes of the crossdisciplinary risk-tool and the overall farm risk score (resulting polygon area), for the 31 partaking farm enterprises (anonymised). Low E. coli burden can still equate to high overall risk if combined with poor farm management and high likelihood of transfer.

\begin{tabular}{|c|c|c|c|c|c|c|c|}
\hline $\begin{array}{l}\text { farm } \\
\text { name }\end{array}$ & burden & obstacles & transfer & infrastructure & $\begin{array}{c}\text { axes } \\
\text { sum }\end{array}$ & $\begin{array}{c}\max \\
\text { risk }\end{array}$ & \% score \\
\hline Farm CH & 0.1 & 3.8 & 4.2 & 4.6 & 12.7 & 40 & 32 \\
\hline Farm HAT & 0.0 & 1.8 & 5.2 & 6.2 & 13.3 & 40 & 33 \\
\hline Farm WY & 0.0 & 3.8 & 7.2 & 3.3 & 14.3 & 40 & 36 \\
\hline Farm M & 0.1 & 6.7 & 5.5 & 2.4 & 14.7 & 40 & 37 \\
\hline Farm HC & 1.0 & 4.8 & 4.0 & 5.0 & 14.8 & 40 & 37 \\
\hline Farm A & 0.2 & 4.2 & 5.0 & 5.5 & 14.9 & 40 & 37 \\
\hline Farm NB & 0.1 & 6.7 & 4.7 & 3.6 & 15.1 & 40 & 38 \\
\hline Farm BH & 0.7 & 5.5 & 4.8 & 4.5 & 15.4 & 40 & 39 \\
\hline Farm CK & 0.5 & 4.7 & 6.3 & 4.2 & 15.6 & 40 & 39 \\
\hline Farm B & 2.3 & 4.0 & 5.1 & 4.4 & 15.8 & 40 & 40 \\
\hline Farm WP & 1.8 & 3.9 & 5.1 & 5.6 & 16.3 & 40 & 41 \\
\hline Farm Co & 0.3 & 6.0 & 5.1 & 5.2 & 16.5 & 40 & 41 \\
\hline Farm Wa & 1.3 & 6.9 & 2.9 & 5.7 & 16.8 & 40 & 42 \\
\hline Farm NI & 0.2 & 5.7 & 4.0 & 7.1 & 16.9 & 40 & 42 \\
\hline Farm N & 1.9 & 5.3 & 6.4 & 3.4 & 17.0 & 40 & 43 \\
\hline Farm SI & 0.1 & 4.8 & 4.9 & 7.2 & 17.0 & 40 & 43 \\
\hline Farm B & 0.3 & 7.3 & 4.6 & 5.1 & 17.3 & 40 & 43 \\
\hline Farm LH & 1.7 & 6.1 & 5.6 & 4.2 & 17.6 & 40 & 44 \\
\hline Farm P & 0.1 & 7.2 & 6.6 & 4.3 & 18.2 & 40 & 46 \\
\hline Farm Wo & 2.7 & 4.6 & 4.8 & 6.6 & 18.6 & 40 & 47 \\
\hline Farm C & 0.9 & 5.4 & 5.0 & 7.6 & 18.9 & 40 & 47 \\
\hline Farm E & 0.7 & 3.6 & 8.2 & 6.6 & 19.1 & 40 & 48 \\
\hline Farm MX & 2.1 & 7.4 & 5.1 & 4.8 & 19.4 & 40 & 49 \\
\hline Farm WM & 0.5 & 4.6 & 7.2 & 7.9 & 20.2 & 40 & 51 \\
\hline Farm S & 6.5 & 5.6 & 3.7 & 4.8 & 20.6 & 40 & 51 \\
\hline Farm MN & 4.9 & 6.9 & 4.0 & 4.8 & 20.6 & 40 & 52 \\
\hline Farm CL & 0.7 & 6.3 & 8.6 & 5.3 & 20.9 & 40 & 52 \\
\hline Farm DR & 1.3 & 5.3 & 7.2 & 7.2 & 21.1 & 40 & 53 \\
\hline Farm HB & 2.4 & 6.9 & 7.0 & 4.8 & 21.1 & 40 & 53 \\
\hline Farm WN & 7.4 & 5.6 & 4.7 & 4.4 & 22.0 & 40 & 55 \\
\hline Farm W & 5.2 & 6.8 & 7.7 & 6.3 & 25.9 & 40 & 65 \\
\hline
\end{tabular}

*Rounded to nearest \%

Farms monitored for microbiological water quality shown in bold 